\title{
EFFECT OF NET SHADING TECHNOLOGY AND HARVEST TIMES ON YIELD AND FRUIT QUALITY OF SWEET PEPPER
}

\author{
AMBróZY, Zs. ${ }^{*}{ }^{*}$ - DAOOD, $\mathrm{H}^{2}{ }^{2}$ - NAGY, Zs. ${ }^{1}$ - DARÁZSI LEDÓ, H. ${ }^{3}$ - HELYES, L. ${ }^{1}$ \\ ${ }^{1}$ Institute of Horticulture, Faculty of Agriculture and Environmental Sciences, Szent István \\ University, Páter Károly street 1., Gödöllö, H-2100, Hungary \\ (phone: +36-2-852-2071) \\ ${ }^{2}$ Regional University Science Centre, Szent István University, Páter Károly street 1., Gödöllö, \\ H-2100, Hungary \\ ${ }^{3}$ Advisory Board of Vegetable-Fruit Producer Organizations (TÉSZ-ÉSZ), Villányi street 35-43., \\ Budapest, H-1118, Hungary \\ *Corresponding author \\ e-mail: ambrozy.zsuzsanna@mkk.szie.hu
}

(Received 24 $4^{\text {th }}$ Mar 2015; accepted $16^{\text {th }}$ Dec 2015)

\begin{abstract}
Shading effects on yield and fruit quality (sunscald, total carotenoid content and ratio of red and yellow pigments) were examined in 'Karpex' red colored sweet pepper hybrid (Capsicum annuum L.). The sampling was performed at two different harvest times; $27^{\text {th }}$ of August and $1^{\text {st }}$ of October in 2013. The photo-selective shading nets were CN red from Israel, and yellow, red, green, and white from Hungary, all with $40 \%$ shade factor. We found a significantly higher yield under the yellow and red net compared with the unshaded control. The yield was more than $50 \%$ higher under the yellow net $\left(33.6 \mathrm{t} \mathrm{ha}^{-1}\right)$, than in the control plot $\left(15.5 \mathrm{t} \mathrm{ha}^{-1} ; \mathrm{F}_{5,12}=10.761, \mathrm{p}<0.001\right)$. All shading nets had a significantly positive effect against sunburn at the first harvest $\left(\mathrm{F}_{5,12}=12.403, \mathrm{p}<0.001\right)$, except for the white shading net. In addition, no sunscald fruit were observed under $\mathrm{CN}$ red net and green net, compared to $4 \mathrm{tha}^{-1}$ losses due to sunburn in the control plot. No sunscald pepper fruit were detected at the second harvest. The total carotenoid content ranged between 163.4 and $338.9 \mu \mathrm{g} \mathrm{g}^{-1}$ fw. Regarding the net shading, we could determine significant difference in total carotenoid content, between white net and the control treatment $\left(\mathrm{F}_{5,12}=4.372, \mathrm{p}=0.017\right)$ at the second harvest. The unshaded control contained more than $50 \%$ less carotenoid than that under the white net. Peppers under the yellow and red nets contained the lowest amount of carotenoids. Overall, significantly more carotenoids were detected at the second harvest, than at the first harvest $\left(\mathrm{F}_{1,24}=220.035, \mathrm{p}<0.001\right)$. In contrast, the ratio of red and yellow pigments was higher at the first harvest. Hence, the earlier harvest is recommended in order to produce pepper fruits with attractive red color. In conclusion, the use of net shading technology resulted in increased yield, reduced sunscald, and can be tailored to improve fruit color.
\end{abstract}

Keywords: Capsicum annuum L., sunscald, carotenoids, redness, photo-selective net

\section{Introduction}

The success of kapia pepper cultivation depends on high yield and quality. The intensive sunlight can cause severe damage, because sunscald fruits do not meet industry standards and their nutritional value is reduced (López-Marín et al., 2013). The deep red tone of the kapia pepper fruits is an important requirement of industry. The carotenoids accurately the ratio of red and yellow pigments determinate the color tone. Carotenoids make the fruit healthier and act as antioxidant in human body, they protects our cells from reactive oxygen and free radicals (Baranski et al., 2005; SunHwa et al., 2007). Carotenoids reduce the risk of degenerative disease such as cardiovascular diseases, stoke, diabetes, cataract and cancer (Deepa et al., 2006). The 
biosynthesis of carotenoids is affected by sunlight and temperature (Schwarz et al., 2010). Exposure to high temperature and radiation can lead to inhibition of carotenoid biosynthesis (Brant et al., 2006).

In the major pepper growing countries (China, Mexico, Turkey, Indonesia and Spain, FAOSTAT 2014) where the problem is the most serious - due to their proximity to the Equator - net shading is a commercial technology to reduce the damaging effect of sunlight. Net shading technology can be a good solution in order to reduce sunscald fruits and produce sweet peppers with improved carotenoid content and attractive red color. By using shading nets, our aim was to avoid the damage caused by extreme weather conditions (high radiation and temperature, hail, heavy rain) and ensure the optimal microclimate for the pepper. Thus we intended to increase the yield and the number of marketable fruits and to reduce sunscald. Due to favorable microclimate we expected increased carotenoid content and especially increased ratio of red pigments. We aimed at the comparison of different shading nets from the point of view the yield, the number of sunscald fruits and the carotenoid content. We examined the same aspects with regard to which harvest time, - the first in summer or the second in autumn - is more favorable for peppers under Hungarian climatic conditions. Based on our findings we would like to recommend a color of shading net.

\section{Review of literature}

\section{Net shading technology}

The effect of photo-selective blue and red screens was evaluated in Brazil with sweet pepper cultivars. The losses due to sunscald and rotting were greater than $35 \%$ under field conditions, while in screen-houses there was less than 5\% (Santana et al., 2012). In Hungary, the most commonly used shading nets in pepper production are green, which is not reported with the literature. The question arises: why do farmers typically use the green net in Hungary? Ledó (2011) described that the green net with $40 \%$ shade caused on average a $25 \%$ decrease in yields and fruit quality of four sweet pepper cultivars compared with the control. Several studies reported the positive effect of different colored shading nets in Capsicum annuum cultivars (Elad et al., 2007; Shahak 2008, Fallik et al., 2009; Goren et al., 2011; Kong et al., 2012; Kong et al., 2013). Elad et al. (2007) observed increased yields with usage shading nets with $25 \%$ SF (white, black) and with $40 \%$ SF (black, blue, blue-silver, silver) compared with the control. Shahak (2008) reported increased yields under pearl and red net compared with black. Fallik et al. (2009) reported significantly higher yield by the usage of red and yellow nets compared with the black of the same SF. Goren et al. (2011) described, that pearl and yellow nets significantly reduced decay incidence compared with the black and red shade nets by $35 \% \mathrm{SF}$. The skin of the fruit under the red and black net was significantly darker than under pearl net. Photo-selective netting can affect the yield and quality of pepper fruits, because it changes radiation spectra and microclimatic conditions (Shahak 2008; Kong et al., 2012). The spectral composition of light can influence the intensity of photosynthesis, and thus, the biomass production because similar photon flux densities of different wavelengths result in different rates of leaf photosynthesis (van Leperen 2012). The photo-selective shading reduces the radiation, thereby reducing plant, air, and soil temperatures, and changes its direction as, well. It lowers the air movement, and increases the relative humidity (Pérez et al., 2006; Elad et al., 2007; Stamps 2009). Oren-Shamir et al. (2001) determined that the colored nets - 
green, red and blue with a 50\% shade factor (SF) - increased light scattering, reaching 46-53\% diffuse light. On average the green net scattered most of the light. The diffuse light increases radiation use efficiency and it has a beneficial effect on timing, yields and quality (Healey et al.,1998; Stamps 2009; Goren et al., 2011; Kong et al., 2013).

\section{Health promoting carotenoids in pepper}

The human body is not capable of synthesizing carotenoids, hence our main sources are vegetables. The red sweet pepper is a rich source of these carotenoids (Baranski et al., 2005). It is well documented that the carotenoids have photo-protective, chemoprotective, and antimutagenic effects and they provide protection against cardiovascular and eye diseases, through the inhibition of singlet oxygen and free radical formation (Baranski et al., 2005; Sun-Hwa et al., 2007). The red color is caused by approximately $80 \%$ capsanthin and approximately $3 \%$ capsorubin, but capsorubin makes the color tone deeper, which is one of the main requirements of the industry (Sun-Hwa et al., 2007). The red pigments account for 55-60\% of carotenoids, thus in the red type peppers the total carotenoid content is higher than in the yellow or green types (Kim et al., 2004).

\section{Different factors influencing the nutritional parameters}

Several studies have described the factors that are most likely to affect quality and nutritional parameters in pepper: genotype (Deepa et al., 2006), irrigation (GonzálezDugo et al., 2007), agronomic and environmental factors (García et al., 2007). Exposure to high temperature and radiation is one of the most common environmental stresses in plants. The growth of pepper begins around $8-12{ }^{\circ} \mathrm{C}$, and it breaks off above $35^{\circ} \mathrm{C}$. The synthesis of plant metabolites - including carotenoids - increase between $22-30{ }^{\circ} \mathrm{C}$ exponentially (Schwarz et al., 2010).

\section{Materials and Methods}

\section{Experimental field conditions}

In 2013 'Karpex' sweet pepper hybrid (Seminis ${ }^{\circledR}$ product, Budapest, Hungary) was grown in the experimental fields of the Szent István University (SIU) in Gödöllö, Hungary $\left(47^{\circ} 59^{\prime} \mathrm{N}, 19^{\circ} 35^{\prime} \mathrm{E}\right)$. 'Karpex' hybrid belongs to the kapia type of sweet peppers and is characterized a slightly flattened conical shape, flat surface, and by dark red color at maturity. Pepper plants were shaded with five different colored photoselective shading nets: red (Ginegar, ChromatiNet, Israel), yellow, red, green, and white (Első Magyar Kenderfonó, Raschel net, Hungary), all with a SF of 40\%, and compared with an uncovered control. The seedlings were transplanted on the $16^{\text {th }}$ of May, and arranged in double rows with a distance of 0.8 between beds and $0.3 \mathrm{~m}$ between the rows and $0.3 \mathrm{~m}$ between the plants. A trellis $2 \mathrm{~m}$ above the ground from locust poles and steel wire was constructed. The different colored nets were erected one behind the other, along the double rows. The sampling was performed randomly by hand at the biological maturity stage on the $27^{\text {th }}$ of August and on the $1^{\text {st }}$ of October. Each sample consisted of three replicates $(n=3)$. The first replicate was harvested from the first twin row, the second from the second and the third from the third twin row. One replicate contained a random sample of 10 healthy fruit from 10 plants and these fruit were considered marketable yield. Meteorological data were provided by a Campbell CR21X 
meteorological instrument (Campbell Scientific Inc., Loughborough, U.K.), recording the precipitation and the temperature six times per hour (Fig. 1).

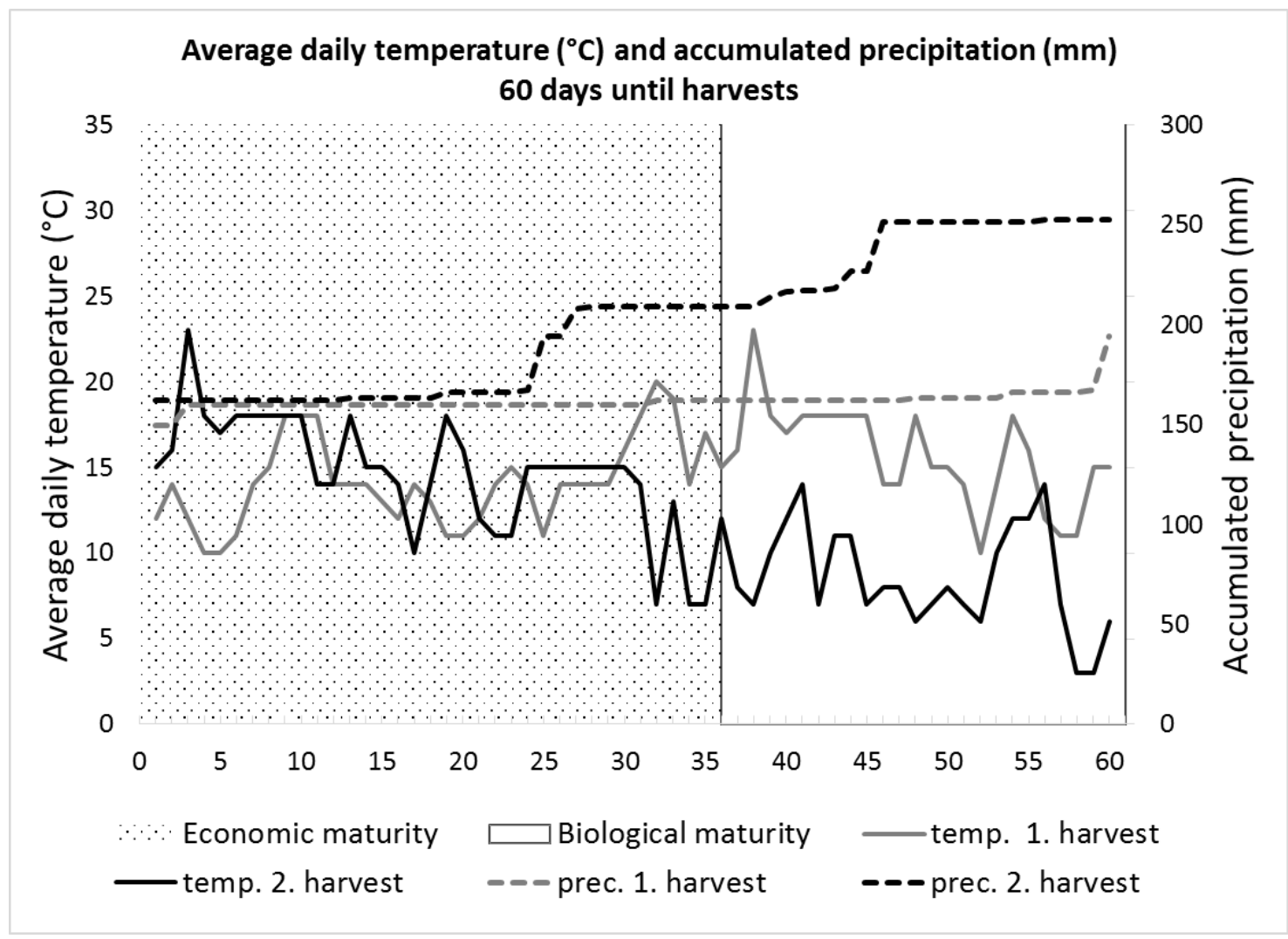

Figure 1. The average daily temperature and accumulated precipitation 60 days (after anthesis) until the harvests. The $x$-axis indicates the days, the value 60 is the harvest day. The grey and the black dashed lines (accumulated precipitation) belong to the y-axis on the right, the grey and the black lines (the average daily temperature) belong to the y-axis on the left side. From the 35th day begins the biological maturity of the pepper fruits (marked with grey filling).

\section{Extraction of carotenoids}

Carotenoids from pepper fruit were extracted following a method of Biacs and Daood (1994). Three grams of a well-homogenized samples were extracted by crushing in a crucible mortar with quartz sand followed by addition of $20 \mathrm{ml}$ methanol to bind water. After decantation of the methanol supernatant to a conical flask, the residues were further crushed and $50 \mathrm{ml}$ of a solvent mixture consisting of 5:1 1,2dichloroethane-methanol were stepwise added and the mixture was pooled with the methanol extract and mechanically shaken for $15 \mathrm{~min}$. The carotenoid-containing phase was passed through in a separating funnel by the addition of 1-2 $\mathrm{ml}$ of water. The lower layer containing carotenoids was dried over anhydrous $\mathrm{Na}_{2} \mathrm{SO}_{4}$ and the solvent was evaporated under vacuum at maximum $40{ }^{\circ} \mathrm{C}$ using a rotary evaporator. The residues were re-dissolved in $5 \mathrm{ml}$ of solvent mixture consisting of 55:35:10 isopropanolacetonitrile-methanol followed by addition of $5 \mathrm{ml}$ methanol. The extract was further cleaned by passing through a $22 \mu \mathrm{m}$ PTEF syringe filter before injection onto the HPLC column. 


\section{HPLC procedure}

A Merck-Hitachi Chromastar liquid chromatographic instrument (Mannheim, Germany) consisting of a Model 5110 pump, a Model 5430 photodiode-array detector and a Model 5210 auto-sampler was used for the HPLC analysis of carotenoids. Operation and data processing were performed by EZchrom Elite software. The unhydrolyzed carotenoid extract was separated on Purospher C-18, $3 \mu \mathrm{m}, 250$ x $4.6 \mathrm{~mm}$ column using gradient elution starting with $7 \%$ water in methanol, changes to $100 \%$ methanol in $3 \mathrm{~min}$, to 100\% isopropanol-acetonitrile-methanol (55:35:10) in $32 \mathrm{~min}$ and returns to 7\% water in methanol in 5 min according to Daood and Biacs (2005). Diodearray detection was adjusted between 190-600 nm to detect carotenoids and characterize their spectra.

\section{Peak identification}

Peak identification was based on comparison of retention and spectral characteristics of each sample peak with those of available standards like $\beta$-carotene, zeaxanthin, $\beta$ cryptoxanthin and capsanthin and with literature data (Baurenfiend, 1981; Socaciu, 2007) when standards were not available. Mono- and di-esters of red and yellow xanthophylls were identified according to their spectral characteristics before and after alkaline hydrolysis (saponification) using thin-layer chromatographic (TLC) method (Vinkler and Kiszel-Richter, 1972). Additionally, chromatographic behavior and spectral characteristics of fatty acid esters were compared with those stated by Wingerath et al., (1996) and Giuffrida et al., (2013) who used similar chromatographic procedure and identified the carotenoid profile using mass spectroscopic and photo diode-array detection in LC-MS systems. The yellow-colored compounds were quantified as $\beta$-carotene equivalent while red colored ones were quantified as capsanthin equivalent.

\section{Data analyses}

The statistical analyses were conducted with IBM SPSS 22 statistical software package (Budapest, Hungary). Three linear models (LM) were designed for yield, total carotenoids, and red/yellow ratio as dependent variables. Explanatory variables were 'harvest time', 'net shading', and their interaction (all of them as factors) in all LM with a 5\% probability level. Post-hoc comparison was made by Tukey's range test. Assumptions of the LM were checked by plot diagnosis, and Levene's test was used to check the homogeneity of variances. The comparison of yield, total carotenoid content and red/yellow ratio was made by two-tailed independent samples t-test, and the distribution of the dependent variable was confirmed by Shapiro-Wilk test of normality.

\section{Results}

\section{Sunscald fruit}

By the first harvest a total of $8.99 \mathrm{t} \mathrm{ha}^{-1}$ sunscald fruit were detected, but we did not find any sunscald fruits at the second harvest. All shading nets had a significantly positive effect against sunscald, except for the white shading net at the first harvest. No sunscald fruit were found under the $\mathrm{CN}$ red or green nets. In contrast, there were $4 \mathrm{t} \mathrm{ha}^{-1}$ 
sunscald fruit in the control plot. Higher amount of sunscald fruit was found without netting compared with the photo-selective nets $\left(\mathrm{F}_{5,12}=12.403\right.$, $\mathrm{p}<0.001 ;$ Fig. 2$)$.

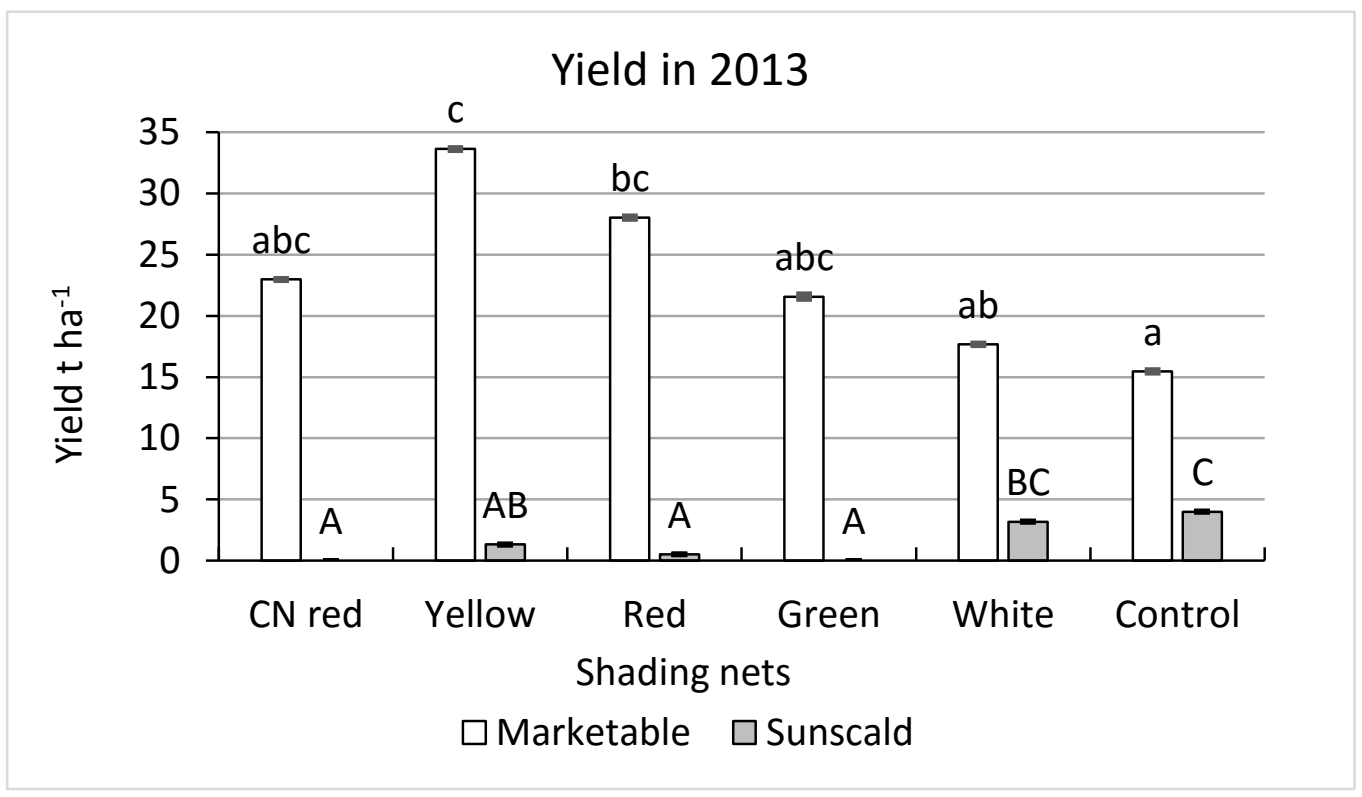

Figure 2. Effect of different colored shading nets on the yield of marketable and sunscald fruits in 2013 (t ha-1). Bars within the same treatment and topped by the same letter are not significantly different according to Tukey's range test at the $5 \%$ level $(n=3)$.

\section{Yield}

Significantly higher yield was found under yellow and red net compared with the control. The lowest yield was found in the control $\left(15.5 \mathrm{t} \mathrm{ha}^{-1}\right)$, it was more than $50 \%$ lower than under yellow net (33.6 $\left.\mathrm{t} \mathrm{ha}^{-1}\right)$ (Fig. 2).

\section{Total carotenoids}

43 carotenoids were identified and quantitatively determined in pepper fruits by HPLC. The total carotenoid content ranged between 163.4 and $338.9 \mu \mathrm{g} \mathrm{g}^{-1} \mathrm{fw}$ (fresh weight basis; Table 1).

There was no interaction between the shading treatment and the different harvest times. Regarding the 'net shading' we could determine significant difference in total carotenoid content, when comparing the white net to the control treatment $\left(\mathrm{F}_{5,12}=4.372\right.$, $\mathrm{p}=0.017$ ) at the second harvest time (Table 1). The unshaded control contained the lowest level of carotenoids, with $163.4 \mu \mathrm{g} \mathrm{g}^{-1}$ during the second harvest in October. This amount was more than $50 \%$ less than that found under the white net. At the first harvest, peppers contained the highest average of total carotenoids under white net, but this difference was not proved statistically. Peppers under the yellow and red nets (except the control) contained the lowest amount of carotenoids.

Likewise, 'net shading', 'harvest time' $\left(\mathrm{F}_{1,24}=220.035, \mathrm{p}<0.001\right)$ resulted a significant effect on total carotenoid content. On average, we found more carotenoids at the second harvest, than at the first harvest (Table 1). At the second harvest the peppers grown under the $\mathrm{CN}$ red the green shading nets and the control contained a 
lower amount of carotenoids, than at the first, while in the other cases the carotenoid content increased.

Among the treatments, the lowest R/Y ratio was detected without netting, while the highest value was found under $\mathrm{CN}$ red net treatment, based on the average of two harvests results, but this difference was not significant.

A significantly higher $\mathrm{R} / \mathrm{Y}$ ratio was observed at the first harvest under $\mathrm{CN}$ red, green, and white shading nets as well as with the control compared to the yellow and red nets (Table 1).

\section{Discussion}

\section{Sunscald fruit}

Due to high temperatures during the vegetative period it was expected that intense sunlight would damage, to a considerable extent, the color of the pepper fruit. We found significantly higher amount of sunscald fruit without netting compared with the photoselective nets at the first harvest $\left(\mathrm{F}_{5,12}=12.403\right.$, $\mathrm{p}<0.001$; Fig. 2$)$. These results agree with those reported by Santana et. al. (2012). The authors found less sunscald fruits $(5 \%)$ under photo-selective shading than under the control $(35 \%)$ in sweet pepper. In case of all shading nets a positive effect was experienced against sunscald except for the white net. We did not find any sunscald fruit under the $\mathrm{CN}$ red or green nets. This is due to the fact, that $\mathrm{CN}$ red and green shading net have the highest and white shading net the lowest absorbance in the photosynthetically active radiation (Szuvandzsiev et al., 2015). Red and green nets increase light scattering (Oren-Shamir et al. 2001). This diffuse light can increase radiation use efficiency, and quality. No sunscald pepper fruits were detected at the second harvest, when the radiation was not as high as at the first harvest.

\section{Yield}

Significantly higher yield was found under yellow and red net compared with the control. This result is consistent with the findings of Fallik et al. (2009), they reported improved fruit yield and quality in pepper when the plants were grown under photoselective shade nets.

\section{Total carotenoids}

Even though we identified and quantitatively determined 43 carotenoids in pepper fruits by HPLC, this study focused on only the amount of total carotenoids, red and yellow pigments responsible for the red tone (Hornero-Méndez and Minguez-Mosquera, 2000). The values recorded for the total carotenoid content in the 'Karpex' hybrid (163.4 and $338.9 \mu \mathrm{g} \mathrm{g}^{-1} \mathrm{fw}$ ) investigated in this work is well above the values reported by Deepa et al. (2007) and Matsufuji et al. (2007). Deepa et al. found $132.5 \mathrm{mg} 100 \mathrm{~g}^{-1}$ $\mathrm{dw}$ that equals to $198 \mu \mathrm{g} \mathrm{g}^{-1} \mathrm{fw}$, in some red-colored vegetable pepper varieties. Matsufuji et al. (2007) compared the total carotenoid content of white, green, yellow, orange and red sweet peppers (Capsicum annuum 'Signal'). Among the mature fruit, 'Signal Red' was the highest with $91.5 \mu \mathrm{g} \mathrm{g}{ }^{-1} \mathrm{fw}$. 
Table 1. Content of total carotenoid, total red and total yellow carotenoids ( $\mu g \mathrm{~g}-1$ ), and the ratio of red and yellow carotenoids under colored shading nets and the control, in 'Karpex' pepper hybrid at different harvest times. Mean ( $n=3) \pm$ standard deviation. Data in the same column bearing the same uppercase letter, and data pairs (Aug. and Oct. harvests) in the same row bearing the same lowercase

letter are not significantly different at the $5 \%$ level (according to Tukey's range test.)

\section{Carotenoid characteristics of 'Karpex' hybrid}

\begin{tabular}{|c|c|c|c|c|c|c|c|c|}
\hline \multirow{2}{*}{ Treatment } & \multicolumn{2}{|c|}{ Total carotenoid } & \multicolumn{2}{|c|}{ Total red } & \multicolumn{2}{|c|}{ Total yellow } & \multicolumn{2}{|c|}{ Red/yellow } \\
\hline & Aug. & Oct. & Aug. & Oct. & Aug. & Oct. & Aug. & Oct. \\
\hline $\mathrm{CN}$ red & $\begin{array}{c}233.94 \pm 34.42 \\
\text { aA }\end{array}$ & $\begin{array}{c}188.39 \pm 18.12 \\
\mathrm{aB}\end{array}$ & $\begin{array}{c}188.47 \pm 26.34 \\
\mathrm{aA}\end{array}$ & $\begin{array}{c}133.09 \pm 13.59 \\
\mathrm{aB}\end{array}$ & $\begin{array}{c}45.47 \pm 9.1 \\
\mathrm{aA}\end{array}$ & $\begin{array}{c}55.3 \pm 6.54 \\
\mathrm{aA}\end{array}$ & $\begin{array}{c}4.2 \pm 0.52 \\
\mathrm{aA}\end{array}$ & $\begin{array}{c}2.42 \pm 0.24 \\
\mathrm{aB}\end{array}$ \\
\hline Yellow & $\begin{array}{c}182.45 \pm 42.99 \\
\mathrm{aA}\end{array}$ & $\begin{array}{c}249.74 \pm 67.77 \\
\text { abB }\end{array}$ & $\begin{array}{c}143.76 \pm 29.65 \\
\mathrm{aA}\end{array}$ & $\begin{array}{c}180.87 \pm 53.1 \\
\text { abA }\end{array}$ & $\begin{array}{c}38.68 \pm 13.8 \\
6 \mathrm{aA}\end{array}$ & $\begin{array}{c}68.87 \pm 15.19 \\
\text { abA }\end{array}$ & $\begin{array}{c}3.92 \pm 0.91 \\
\mathrm{aA}\end{array}$ & $\begin{array}{c}2.6 \pm 0.27 \\
\mathrm{aA}\end{array}$ \\
\hline Red & $\begin{array}{c}187.07 \pm 26.36 \\
\mathrm{aA}\end{array}$ & $\begin{array}{c}259.75 \pm 71.42 \\
\text { abB }\end{array}$ & $\begin{array}{c}147.07 \pm 24.98 \\
\mathrm{aA}\end{array}$ & $\begin{array}{c}194.19 \pm 53.7 \\
\mathrm{abA}\end{array}$ & $\begin{array}{c}40.00 \pm 2.31 \\
\mathrm{aA}\end{array}$ & $\begin{array}{c}65.56 \pm 17.73 \\
\mathrm{abA}\end{array}$ & $\begin{array}{c}3.67 \pm 0.55 \\
\mathrm{aA}\end{array}$ & $\begin{array}{c}2.96 \pm 0.04 \\
\mathrm{aA}\end{array}$ \\
\hline Green & $\begin{array}{c}212.49 \pm 41.11 \\
\mathrm{aA}\end{array}$ & $\begin{array}{c}184.44 \pm 46.05 \\
\mathrm{abB}\end{array}$ & $\begin{array}{c}168.07 \pm 33.61 \\
\mathrm{aA}\end{array}$ & $\begin{array}{c}134.18 \pm 36.92 \\
\mathrm{aA}\end{array}$ & $\begin{array}{c}44.42 \pm 8.67 \\
\mathrm{aA}\end{array}$ & $\begin{array}{c}50.27 \pm 9.13 \\
\mathrm{aA}\end{array}$ & $\begin{array}{c}3.79 \pm 0.39 \\
\mathrm{aA}\end{array}$ & $\begin{array}{c}2.64 \pm 0.26 \\
\mathrm{aB}\end{array}$ \\
\hline White & $\begin{array}{c}248.61 \pm 37.76 \\
\mathrm{aA}\end{array}$ & $\begin{array}{c}338.87 \pm 14.28 \\
\text { bB }\end{array}$ & $\begin{array}{c}195.35 \pm 28.4 \\
\mathrm{aA}\end{array}$ & $\begin{array}{c}250.30 \pm 6.34 \\
\mathrm{bA}\end{array}$ & $\begin{array}{c}53.26 \pm 9.36 \\
\mathrm{aA}\end{array}$ & $\begin{array}{c}88.57 \pm 8.18 \\
\text { bB }\end{array}$ & $\begin{array}{c}3.68 \pm 0.13 \\
\mathrm{aA}\end{array}$ & $\begin{array}{c}2.84 \pm 0.2 \\
\mathrm{aB}\end{array}$ \\
\hline Control & $\begin{array}{c}228.20 \pm 24.12 \\
\mathrm{aA}\end{array}$ & $\begin{array}{c}163.37 \pm 16.16 \\
\mathrm{aB}\end{array}$ & $\begin{array}{c}180.88 \pm 16.38 \\
\mathrm{aA}\end{array}$ & $\begin{array}{c}116.47 \pm 11.64 \\
\mathrm{aB}\end{array}$ & $\begin{array}{c}47.32 \pm 8.26 \\
\mathrm{aA}\end{array}$ & $\begin{array}{c}46.91 \pm 4.55 \\
\mathrm{aA}\end{array}$ & $\begin{array}{c}3.87 \pm 0.42 \\
\mathrm{aA}\end{array}$ & $\begin{array}{c}2.48 \pm 0.03 \\
\mathrm{aB}\end{array}$ \\
\hline
\end{tabular}


By the second harvest, significantly higher total carotenoid content was found under white net grown peppers, than in the control treatment (more than 50\%), $\left(\mathrm{F}_{5,12}=4.372, \mathrm{p}=0.017\right)$. The control contained the lowest level of carotenoids, with $163.4 \mu \mathrm{g} \mathrm{g}^{-1}$ during the second harvest. However, peppers contained the highest average of carotenoids under white net at the first harvest, but this difference was not significant. Interestingly, peppers under the yellow and red nets contained the lowest amount of carotenoids.

At the second harvest the peppers grown under the $\mathrm{CN}$ red and the green shading nets and the control contained a lower amount of carotenoids, then at the first harvest. Most probably because of the higher absorbance of $\mathrm{CN}$ red and green nets, while in the other cases the carotenoid content increased. The unshaded control contained lower amount of carotenoids most likely due to the unfavorable microclimate (wind, lower temperature and lower relative humidity).

We found more carotenoids at the second harvest, than at the first harvest $\left(\mathrm{F}_{1,24}=220.035, \mathrm{p}<0.001\right)$, (Table 1). This is because on the day before the first harvest there was a heavy rainfall $(27.1 \mathrm{~mm})$ which diluted the nutritional value, so the carotenoid content of the peppers. In the fifteen days preceding the second harvest it rained only once and its amount was only $1 \mathrm{~mm}$ (Fig. 1).

As mentioned above, in sweet red pepper the red pigments are mainly capsanthin and capsorubin and their mono- and di-esters, which are accountable for the red color. Because of the parallel presence of the red and yellow pigments in the fruits, the appearance of the redness is expressed mostly by the ratio of red and yellow pigments $(\mathrm{R} / \mathrm{Y}$ ratio) in the fruits.

Based on the average of two harvests results the highest $R / Y$ ratio was detected under $\mathrm{CN}$ red net and the lowest without netting but this was not proved statistically. Results of Goren et al. (2011) who reported significantly darker skin color under the red net than under pearl net, in red bell peppers ('Romans' and 'Vergesa') supported our above-mentioned findings. During the data analysis, we observed a significantly higher $\mathrm{R} / \mathrm{Y}$ ratio at the first harvest in case of $\mathrm{CN}$ red, green, and white shading nets and the control than at the second harvest (Table 1). This higher ratio might be due to the almost $10{ }^{\circ} \mathrm{C}$ higher average temperature during the first harvest (Fig. 1).

The obtained data suggest that yellow shading net can be used by red sweet pepper growers to achieve greater yields compared with the standard practice of using green net or no shading. In contrast green net and $\mathrm{CN}$ red net shading of sweet peppers could be an optimal solution against sunscald fruits by reducing high radiation stress. Although, the white shading net did not result in the best yield, it showed the highest total carotenoid content values at both harvest times. Despite that the total carotenoid content of the fruits was higher at the second harvest, in order to produce sweet peppers with attractive red color, the first harvest is recommended. To support our findings, we also recommend the repetition of the experiment and to expand it other measuring devices in each treatment.

As conclusion, by heat, dry weather condition with high solar radiation it is highly recommended to use the $\mathrm{CN}$ Red net to receive increased ratio of attractive red colored marketable fruits. 


\section{REFERENCES}

[1] Baranski, R., M. Baranska, and H. Schulz. (2005): Changes in carotenoid content and distribution in living plant tissue can be observed and mapped in situ using NIR-FTRaman spectroscopy. - Planta 222:448-457.

[2] Bauernfeind J.C. (1981): Carotenoids as colorants and vitamin A precursors. Technological and nutritional applications. - Academic Press, Inc., New York.

[3] Brant, S., Z., Pék, E., Barna, A., Lugasi, and L., Helyes. (2006): Lycopene content and colour of ripening tomatoes as affected by environmental conditions - J. of the Sci. of Food and Agr. 86:(4):568-572.

[4] Biacs, P., and H.G. Daood. (1994):. High-performance liquid chromatography 2 with photodiode-array detection of carotenoids and carotenoid esters in fruits and vegetables. J. Plant Physiol. 143:520-525.

[5] Daaood, H.G., and P. Biacs. (2005): Simultaneous determination of Sudan dyesand carotenoids in red pepper and tomato products. - J. Chromatog. Sci. 43:461-465.

[6] Deepa, N., C. Kaur, B. Singh, and H.C. Kapoor. (2006): Antioxidant activity in some red sweet pepper cultivars. - J. Food Compos. Anal. 19:572-578.

[7] Deepa, N., C. Kaur, B. George, B. Singh, and H.C. Kapoor. (2007): Antioxidant constituents in some sweet pepper (Capsicum annuum L.) genotypes during maturity. LWT - Food Sci. Technol. 40:121-129.

[8] Elad, Y., Y. Messika, M. Brand, D.R. David, and A. Sztejnberg. (2007): Effect of colored shade nets on pepper powdery mildew (Leveillula taurica). - Phytoparasitica 35:285-299.

[9] Fallik, E., S. Alkalai-Tuvia, Y. Parselan, Z. Aharon, A. Elmann, Y. Offir, E. Matan, H. Yehezkel, K. Ratner, N. Zur, and Y. Shahak. (2009): Can colored shade nets maintain sweet pepper quality during storage and marketing? - Acta Hort. 830:37-44.

[10] FAOSTAT (2014): FAOSTAT. http://faostat.fao.org. Accessed 15 Jul 2014

[11] García, M.I., M. Lozano, V.M. de Espinosa, M.C. Ayuso, M.J. Bernalte, M.C. VidalAragón, and M.M. Pérez. (2007): Agronomic characteristics and carotenoid content of five Bola-type paprika red pepper (Capsicum annuum L.) cultivars. - Scientia Hort. 113:202-207.

[12] Giuffrida, D., P. Dugo, G. Torre, C. Bignardi, A. Gavazza, C. Corradini, and G. Dugo. (2013): Characterisation of 12 Capsicum varieties by evaluation of their carotenoid profile and pungency determination. - Food Chem. 140:794-802.

[13] González-Dugo, V., F. Orgaz, and E. Fereres. (2007): Responses of pepper to deficit irrigation for paprika production. - Scientia Hort. 114:77-82.

[14] Goren, A., S. Alkalai-Tuvia, Y. Perzelan, E. Fallik, and Z. Aharon. (2011): Photoselective shade nets reduce postharvest decay development in pepper fruits. - Adv. Hort. Sci. 25:26-31.

[15] Healey, K.D., G.L. Hammer, K.G. Rickert, and M.P. Bange. (1998): Radiation use efficiency increases when the diffuse component of incident radiation is enhanced under shade. - Aust. J. Agric. Res. 49:665-672.

[16] Hornero-Méndez, D. and M.I. Minguez-Mosquera. (2000): Xanthophyll esterification accompanying carotenoid overaccumulation in chromoplast of Capsicum annuum ripening fruits is a constitutive process and useful for ripeness index. - J. Agric. Food Chem. 48:1617-1622.

[17] Kim, S., J. Park, and I.K. Hwang. (2004): Composition of main carotenoids in Korean red pepper (Capsicum annuum, L.) and changes of pigment stability during the drying and storage process. - J. Food Sci. 69:39-44.

[18] Kong, Y., L. Avraham, Y. Perzelan, S. Alkalai-Tuvia, K. Ratner, Y. Shahak, and E. Fallik. (2013): Pearl netting affects postharvest fruit quality in "Vergasa" sweet pepper via light environment manipulation. - Scientia Hort. 150:290-298. 
[19] Kong, Y., L. Avraham, K. Ratner, and Y. Shahak. (2012): Response of photosynthetic parameters of sweet pepper leaves to light quality manipulation by photoselective shade nets. - Acta Hort. 956:501-506.

[20] Ledó D.H. (2011): A vándorfólia alatti paprikatermesztés tapasztalatai. (Pepper cultivation is in the experience of mobile plastic house; In Hungarian) - ZöldségGyümölcs Piac és Technológia 8:10-12.

[21] López-Marín, J., A. González, F. Pérez-Alfocea, C. Egea-Gilabert, and J.A. Fernández. (2013): Grafting is an efficient alternative to shading screens to alleviate thermal stress in greenhouse-grown sweet pepper. - Scientia Hort. 149:39-46.

[22] Matsufuji, H., K. Ishikawa, O. Nunomura, M. Chino and M. Takeda. (2007): Antioxidant content of different coloured sweet peppers, white, green, yellow, orange and red (Capsicum annuum L.) Intern. - J. Food Sci. Technol. 42:1482-1488.

[23] Oren-Shamir, M., E. E. Gussakovsky, E. Shpiegel, A. Nissim-Levi, K. Ratner, R. Ovadia, Y.E. Giller, and Y. Shahak. (2001): Coloured shade nets can improve the yield and quality of green decorative branches of Pittosporum variegatum. - J. Hort. Sci. Biotechnol. 76:353-361.

[24] Pérez, M., B.M. Plaza, S. Jiménez, M.T. Lao, J. Barbero, and J.L. Bosch. (2006): The radiation spectrum through ornamental net houses and its impact on the climate generated. - Acta Hort. 719:631-636.

[25] Santana, J.Q., M.A. Balbino, T.R. Tavares, R.S. Bezerra, J.G. Farias and R.C. Ferreira. (2012): Effect of photoselective screens in the development and productivity of red and yellow sweet pepper. - Acta Hort. 956:493-500.

[26] Schwarz, D., Y. Rouphael, G. Colla, and J.H. Venema. (2010): Grafting as a tool to improve tolerance of vegetables to abiotic stresses: thermal stress, water stress and organic pollutants. - Scientia Hort. 127:162-171.

[27] Shahak, Y. (2008): Photo-selective netting for improved performance of horticultural crops. A review of ornamental and vegetable studies carried out in Israel. - Acta Hort. 770:161-168.

[28] Socaciu, C. (2008): Food Colorants: Chemical and Functional Properties. Boca Raton. London, New York: CRC Press.

[29] Stamps, R.H. (2009): Use of colored shade netting in horticulture. - HortScience 44:239241.

[30] Sun-Hwa, H., K. Jung-Bong, P. Jong-Sug, L. Shin-Woo, and C. Kang-Jin. (2007): A comparison of the carotenoid accumulation in Capsicum varieties that show different ripening colors: deletion of the capsanthin-capsorubin synthase gene is not a prerequisite for the formation of a yellow pepper. - J. Exp. Bot. 58:3135-3144.

[31] Szuvandzsiev, P., A., Vajnai, Zs., Ambrózy, D. H. Ledó. (2015): Színes árnyékoló hálók alkalmazása szabadföldi kápia paprikafajtáknál. (The usage of colored shade nets by open field grown kapia peppers.) Agrofórum (26) 6:132-134.

[32] Vinkler, M. and M. Kiszel-Richter. (1972): A thin-layer chromatographic method to determine the pigment content (components) in the pericarp of paprika. - Acta Alimentaria 1:41-58.

[33] van Leperen W. (2012): Plant morphological and developmental responses to light quality in a horticultural context. - Acta Hort. 956:131-139.

[34] Wingerath, T., W. Stahl, D. Kirsch, R. Kaufmann, and H. Sies. 1996. Fruit juice carotenol fatty acid esters and carotenoids as identified by matrix-assisted laser desorption ionisation (MALDI). - J. Agric. Food Chem. 44:2006-2013.

\section{ELECTRONIC APPENDIX}

Electronic appendix 1: Matured red peppers

Electronic appendix 2: The scale model of the experiment 